\title{
Detection and characterization of protein oligomeric species by light scattering methods: myosin light chain kinase supramolecular structures
}

\author{
A. M. Filenko \\ Institute of Physiology, Taras Shevchenko Kiev University, Ukraine \\ Volodymyrska str. 64, Kiyw, 01033, Ukiaine
}

\begin{abstract}
Modern multi-angle light scattering, fast protein liquid chromatography and laser correlation spectroscopy used together give rather complete information about the distribution of different protein particles in solution and their characteristics. The data received by these methods on smooth muscle myosin light chain kinase $(M L C K)$ as the object of investigation suggest that MLCK exists in solution as a mixture of oligomeric, dimeric and monomeric particles which contents at ionic strength close to physiological constitute 2, 53 and 45 wt. \% correspondingly. An important point is that supramolecular kinase species content in eluate from a gel filtration column was much higher than their content at equilibrium. The contributions of oligomer, dimer and monomer in eluate at the exit from the column were 5.3, 81.5 and 13.2 wt. \% accordingly. All three kinase species are characterized by prolonged lifetime. The transition from pure dimer into equilibrium state lasts for about $10 \mathrm{~min}$. The kinase dimer is a rod-like structure with molecular mass of about $2 \cdot 10^{5} \mathrm{kDa}$ and root mean square (RMS) radius $R_{\mathrm{g}} 22 \mathrm{~nm}$. Oligomer is characterized by $R M S$ radius $R_{\mathbf{g}} 80 \mathrm{~nm}$. Its structure may be presented as a helical ring containing 10 kinase molecules per turn with a number of turns about 10. Another more realistic explanation of the data obtained involves a rod-like or elongated spiral model according to which 6 kinase molecules, arranged in line or elongated spiral, form one structural unit, which must be a real oligomer (hexamer). About 17 such structural units, associated in parallel, form aggregates with molecular mass of about $10^{7} k D a$. Kinase spiral hexamer fits well the structure of smooth myosin filament with which the kinase is in close contact in vivo. Preliminary experiments with a number of other proteins (myosin, myosin subfragment 1, bovine serum albumin, chemotrypsin, papain) showed that all of them form supramolecular structures with prolonged time of transition from pure species to equilibrium distribution of monomers and supramolecular structures.
\end{abstract}

Introduction. Many proteins are known to function in living cell as supramolecular structures, which include 2 and more molecules [1]. For instance the oligomerdependent modification of enzyme activity is well demonstrated for such proteins as muscle phosphofructokinase [2-4] or erythrocyte $\mathrm{Ca}^{2+}$-ATPase [5]. The determination of real molecular weight and size of different molecular species is of vital importance for their characterization. At present there is no more fundamental tool for measuring mass and size of molecules than light scattering in conjunction with liquid chromatography. This technique has been developing intensively for last decades $[6-12]$ and now

(C) A. M. FILENKO, 2000 complies with the most inexorable demands of many researchers.

In this paper we demonstrate the possibilities of this new approach for characterization of myosin light chain kinase (MLCK), a key regulatory enzyme of smooth muscle contractile system. We have also used the laser correlation spectroscopy, which along with multi-angle light scattering has enabled us to find out equilibrium distribution of different kinase species in weight percents. These two methods used together permit to obtain rather complete characterization of proteins studied.

In our investigations we have used for the first time the procedure of decomposition of mass sensitive and light scattering elution profiles into individual monopeaks that allows more careful analysis of the 
data obtained. We have also used for the first time the interruption of elution in specified points to evaluate time of different species transition to equilibrium state.

Materials and Methods. Protein preparation. MLCK and $\mathrm{Ca}^{2+}$-calmodulin (CaM) were purified from turkey gizzard as described elsewhere [13-15]. Their concentrations were determined using absorption coefficient of $A_{278}{ }^{\prime} \%=11.4$ and $A_{278}{ }^{\circ} \%=1.0$, respectively, for MLCK and CaM [16]. All light scattering experiments were carried out in the buffer AA of the following composition (mM): $\mathrm{KCl}, 60$; $\mathrm{MgCl}_{2}, 2$; dithioerythritol, 0.5 ; imidazole, 10 ; with $\mathrm{pH}$ adjusted to 7.5 at $4{ }^{\circ} \mathrm{C}$. Unless otherwise stated $100 \mathrm{mM} \mathrm{NaCl}$ was added to this buffer during all measurements. All other experimental details are given in the corresponding legends to figures.

Laser correlation spectroscopy. Laser correlation spectroscopy (LCS) was applied to detect directly different MLCK species in solution. Helium-neon laser («Spectrophysics», USA) operating in one mode regime with wavelength $632.8 \mathrm{~nm}$ and power $50 \mathrm{~mW}$ was used as the light source. Laser beam was focused by precision optic system («Optimation $\mathrm{GmbH}$, Germany). Emission scattered by the solution studied was collected by the system of lenses at right angles to the laser beam direction. To identify the kinase particles some experiments were performed on light scattering dependence on the angle of registration. The apparatus was supplied with Goniometer ALV/SP-86 («Optimation GmbH»). Autocorrelation function of scattered light intensity fluctuations was measured by correlator K7032 («Malvern, Instruments Ltd.», UK). Analysis of the autocorrelation functions obtained was carried out on PC according to the regulation procedure described elsewhere [17]. LCS together with the mathematical program of regulation enables to obtain information about both effective hydrodynamic diameters of particles and their relative distribution in solution. The results of sample measurements by the LCS method are presented as a histogram, which reflects the form of the particle size distribution function. The bar height in the histogram is proportional to the relative contribution of the given size particles into the total light scattering spectrum in a given interval. The regulation program reconstructs the size distribution function in 32 points. Because of the broad range of the particle sizes the distribution function is presented in the logarithmic scale. To get rid of dust particles the protein solution was cleared before measurement with Millipore filter $(0.22 \mu \mathrm{m})$.

Multi-angle light scattering photometry. Multiangle laser light scattering in conjunction with the system of fast protein liquid chromatography (FPLC) was used to obtain characteristics of the MLCK species (molecular mass and size) in the course of their elution from chromatographic column. Light scattering was measured on the Wyatt Dawn multiangle laser photometer, model F ( Wyatt Technology Corporation», USA) at the laser wavelength $632.8 \mathrm{~nm}$. Signals from 18 photodiodes were sent to a 19 channel $\mathrm{A} / \mathrm{D}$ converter and then to a computer. The 19th channel was used for a signal from a mass sensitive UV detector placed between the column and flow cell of the photometer. Standard base FPLC ( $\ll$ Pharmacia LKB Biotechnology», Sweden) included the following elements: controller GP-250, high precision pump P-500, valve V-7 with $500 \mu 1$ loop, recorder REC-102, ultraviolet monitor UV-1. $8 \mathrm{ml}$ gel-filtration column $(6 \times 284 \mathrm{~mm})$ was packed with Sephacryl S-300. The connecting tubing between the column and the photometer was selected of a possible minimal length so that UV monitor - Dawn photometer volume delay was $0.16 \mathrm{ml}$ and column - UV monitor delay was $0.1 \mathrm{ml}$. Eluent flow rate was $0.25 \mathrm{ml} / \mathrm{min}$. All solutions before using them for chromatography were carefully degassed and filtered through Millipore $0.22 \mu \mathrm{m}$.

Light scattering data were analyzed on PC using Wyatt ASTRA software. At calculations we assumed values for specific refractive index increment $d n / d c=$ $=0.17 \mathrm{ml} / \mathrm{g}$ and for the second virial coefficient $\mathrm{A} 2=$ $=0$. The least-squares fit (LSF) degree was chosen 2 because of rather large MLCK oligomer size. Wyatt EASI software was used to plot the calculated data.

Results. Distribution of different MLCK species in solution at equilibrium. We evaluated MLCK species distribution by size using LCS method [18]. Fig. 1 shows typical pattern of such distribution for the kinase solution at $4.9 \mu \mathrm{M}$ concentration. More correct data obtained as average of 17 measurements are following:

Diameters

Average \pm standard deviation

$\begin{array}{rc}D_{\mathrm{av}}{ }^{\circ}, \mathrm{nm} & 158.3 \pm 17.8 \\ D_{\mathrm{av}}{ }^{\circ}, \mathrm{nm} & 52.3 \pm 4.4 \\ \% & 20.2 \pm 3.2 \\ D_{\mathrm{av}}{ }^{\mathrm{m}}, \mathrm{nm} & 36.9 \pm 3.6 \\ \% & 8.6 \pm 1.2 \\ \% & 10.7 \pm 3.2\end{array}$

where $D_{\mathrm{av}}{ }^{\mathrm{m}}, D_{\mathrm{av}}{ }^{\mathrm{d}}, D_{\mathrm{av}}{ }^{0}$ are average hydrodynamic diameters of MLCK monomer, dimer and oligomer, respectively.

Light scattering in the interval of $1266-5000 \mathrm{~nm}$ 


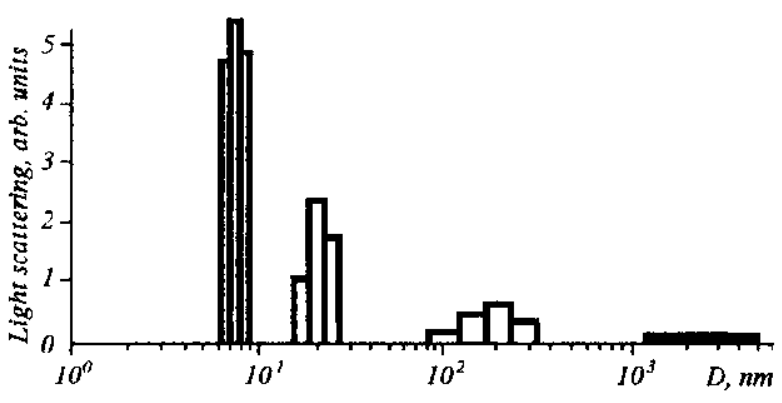

Fig. 1. Particle size distribution of MLCK obtained by LCS method. Experimental conditions: MLCK concentration $4.9 \mu \mathrm{M}$; buffer AA+ $100 \mathrm{mM} \mathrm{NaCl}$. Hydrodynamic diameter of particles $D_{\mathrm{aw}}$ (in $\mathrm{nm}$ ) is plotted in logarithmic scale for convenience. The Fig. shows data obtained for one experiment. Averages for all data are given in text

occurs due to the presence of small quantity of the dust particles, which are very difficult to remove completely by the filtration. The other components were related to the kinase particles, which was confirmed by the dependence of their scattering on the angle (data not shown). It should be pointed that the regularisation program used in the LCS method provides size for spherical particles. Therefore, hydrodynamic sizes obtained by this method for globular proteins are close to their true sizes, that we were able to confirm in control experiments with bovine serum albumin. However, the hydrodynamic size obtained for proteins differing strongly from sphere is a rather conditional value. It applies in full measure to MLCK which was evaluated by ultracentrifugation method to be a rod-shaped molecule of $50 \mathrm{~nm}$ in length and $2.2 \mathrm{~nm}$ in diameter [19]. Close by dimentions $(60 \times 2 \mathrm{~nm})$ is myosin subfragment-2 (SF2) [20]. SF2 hydrodynamic diameter was found by the LCS method to be of $10.8 \mathrm{~nm} \mathrm{[21].} \mathrm{Accor-}$ dingly, we identified particles with $D_{\mathrm{av}}=7.5 \mathrm{~nm}$ in 6-9 nm interval (Fig. 1) as MLCK monomers, possibly with some impurity of smaller species corresponding to the kinase larger proteolytic fragments. The kinase dimer length is twice as that of the monomer [19]. This was confirmed by the presence of particles with $D_{\mathrm{av}}=21.2 \mathrm{~nm}$ in the interval of $16-26 \mathrm{~nm}$. The particles with $D_{\mathrm{av}}=162.0 \mathrm{~nm}$ in $79-317 \mathrm{~nm}$ interval seem to represent the kinase oligomer species. More correct $D_{\text {av }}$ values, used in further calculations, were obtained as an averages of all experimental data (see above). They are 8.6, 20.2 and $\mathbf{1 5 8 . 3}$ for monomer, dimer and oligomer, respectively.

It must be emphasized that owing to the small size of CaM molecules and their low concentration the contribution of the light scattering from CaM was negligible under our experimental conditions. The results obtained showed that $\mathrm{Ca}^{2+}-\mathrm{CaM}$ binding to the kinase at both high and low MLCK to CaM ratios had practically no influence on the size of enzyme species and their relative concentrations, which were almost the same as for inactivated enzyme (apoenzyme).

Elution of different $M L C K$ species from chromatographic columns. To get information about the different kinase species we investigated light scattering of the kinase eluting from a short gel filtration column using the FPLC set-up connected to the Wyatt multi-angle light scattering photometer. The column did not serve to separate the species but to produce continuous distribution of the kinase at wide range of its concentrations, besides removing the troublesome dust particles. Fig. 2, $A$, shows characteristic elution profiles obtained with the FPLC UV-monitor (curve I) and Wyatt DAWN light scattering photometer (curve 2). In the case of a monodisperse sample these curves must coincide within some constant factor [12]. In our case they have complex shape as a result of several elution peaks overlapping. Using similar plots obtained for monodisperse systems (bovine serum albumin, insulin, highly aggregated kinase preparations, polysterene of $M_{\mathrm{r}}=30 \mathrm{kDa}$ and $M_{\mathrm{r}}=$ $=200 \mathrm{kDa}$ ) we decomposed these plots into contributions from individual peaks (Fig. $2, B$ ). Analogous approach was used to decompose complex heat absorption profiles into single components [22]. The main requirements to be satisfied by this procedure are the following: a) the sum of the monopeaks must produce the original elution profile; b) the corresponding light scattering and UV-absorption monopeaks must coincide within some constant factor. As shown in Fig. 2, B, UV-adsorption curve $(I)$ is decomposed into three overlapping monopeaks with maxima at $3.8 \mathrm{ml}\left(a^{0}\right), 5.0 \mathrm{ml}\left(a^{\mathrm{d}}\right)$ and $6.4 \mathrm{ml}\left(a^{\mathrm{m}}\right)$. We assigned these peaks, respectively, to the oligomeric, dimeric and monomeric kinase species. They correspond to the overlapping monopeaks $s^{\circ}, s^{d}$ and $s^{m}$ of the light scattering profile. The peak $s^{1}$ clearly results from the light scattering of the column «debris». It also appears under analogous conditions on the elution profiles of bovine serum albumin, myosin, myosin subfragment $\mathrm{Sl}$ as well as other proteins. There are small contributions of the elution plots for which the monopeaks do not overlap and which, therefore, correspond to the individual kinase species: 

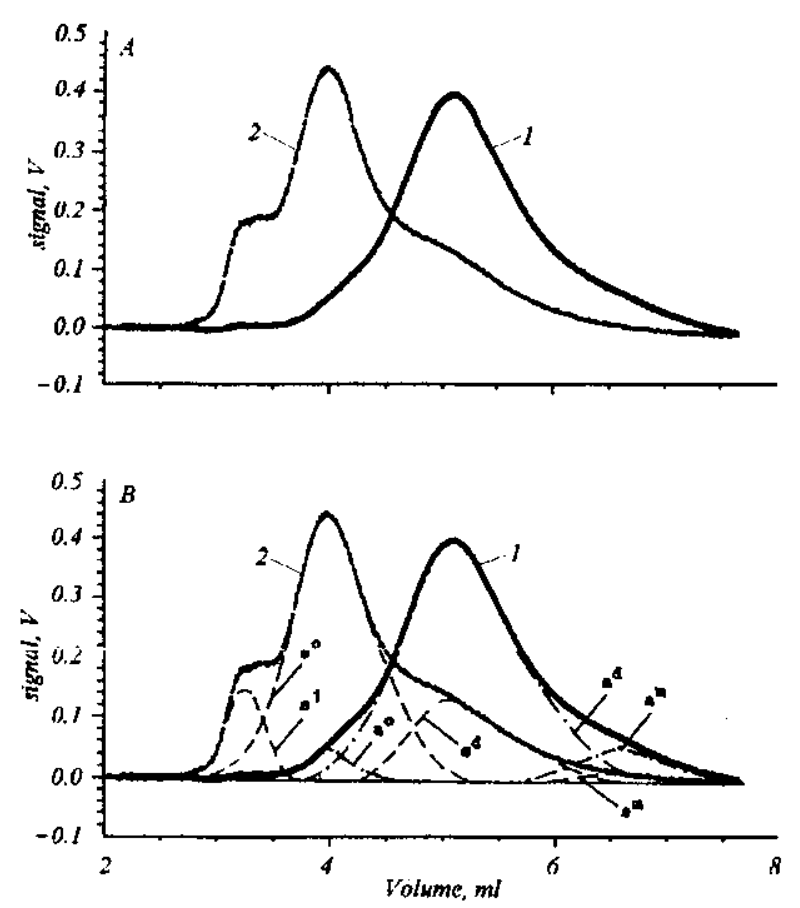

Fig. 2. Elution profiles obtained during MLCK gel filtration: $A$ original curves ( 1 , UV-absorption; 2 , light scattering); $B \longrightarrow$ decomposition of elution profiles into monopeaks of absorption $\left(a^{b}\right)$ and light scattering $\left(s^{\prime}\right)$ where index $* 0 *$ represents the oligomer, *d* the dimer and $* m *$ the monomer; $s t$ corresponds to light scattering of the column «debris". Total mass of MLCK applied to the column was $0.56 \mathrm{mg}(500 \mu \mathrm{l})$. Flow rate was $0.25 \mathrm{ml} / \mathrm{min}$

3.6-3.7 $\mathrm{ml}$ (oligomer), 5.1-5.5 ml (dimer) and $7.0-7.5 \mathrm{ml}$ (monomer). These intervals can be used to calculate the relative contributions of the individual kinase species into the light scattering profiles.

More accurate results we obtained using in our calculations corresponding monopeak area ratios (Table 1). The table shows that, at the same weight concentrations, the oligomer light scattering was 35 times larger than that of the dimer while the latter about 3 times larger than that of the monomer. The weight contributions of the kinase oligomer, dimer and monomer in the eluate at the exit from the column were $5.3,81.5$ and $13.2 \%$ accordingly. Large contribution of the oligomer into the light scattering plot (Fig. 2, B, curve 2) at relatively small weight fraction is the result of its very high light scattering level. These values together with the LCS data obtained for the individual kinase species at equilibrium and the relative contributions $\delta^{\prime}$ of these
Table I

Contribution of MLCK species to elution profiles for gel filtration column

\begin{tabular}{l|c|c|c}
\hline \multicolumn{1}{c|}{ Kinase specles } & Oligomer & Dimer & Monomer \\
\hline $\begin{array}{l}\text { Area of scattering monopeak, } \\
s^{i *}\end{array}$ & 122.0 & 53.6 & 3.0 \\
$\begin{array}{l}\text { Area of UV-absorption } \\
\text { monopeak, } a^{i *}\end{array}$ & 11.0 & 170.6 & 27.7 \\
$\begin{array}{l}\text { The amount in eluate, wt. \%** } \\
\text { Relative contribution to light }\end{array}$ & 5.3 & 81.5 & 13.2 \\
scattering, $\delta^{1 * * *}$
\end{tabular}

*Areas of individual monopeaks (see Fig. 2, B) were found by weighting. Index wit corresponds to 0 - oligomer, $d$ - dimer or $m$ - monomer; **This value was estimated from UV absorption monopeaks $\left(\mathrm{a}^{i}\right)$ taking into account that total area of all monopeaks is $100 \% ; * * *$ This parameter was calculated from the expression: $\delta^{i}=$ - (area $s^{i} /$ area $\left.d^{j}\right) /\left(\right.$ area $s^{d} /$ area $\left.a^{d}\right)$; it represents light scattering of MLCK oligomer and monomer relative to dimer assuming that wt. \% concentrations of all three species are equal.

species into light scattering (see up) allows to calculate the relative content of the oligomers, dimers and monomers at equilibrium (Table 2).

$M_{r}$ and $R M S$ radius for different MLCK species. Fig. 3 shows the curves of molecular weight and root mean square (RMS) radius vs. elution coordinate which were calculated using Wyatt ASTRA and Wyatt EASI software. These curves have characteristic $S$-like form. The data calculated in the elution interval of 5.5 to $7.0 \mathrm{ml}$ are not reliable enough, especially for RMS radius, owing to the poor light scattering by the monomer particles. Due to the oligomer and dimer peaks overlapping in the 3 to $5 \mathrm{ml}$ interval the calculations for each elution slice give weight-average molecular weights and weight-average RMS radii. These values change smoothly along the elution profile accordingly to the weight ratio change of the MLCK species. The characteristic feature of the curves given in Fig. 3 is a rapid growth of the molecular weight with a decrease in elution coordinate (by a factor of 102 in the interval of 5 to $3.6 \mathrm{ml}$, Fig. $3, A$ ) at the relatively small $\mathrm{RMS}$ radius increase (22 to $80 \mathrm{~nm}$, Fig. 3, B) corresponding to such dramatic change of molecular weight.

Using the intervals of elution profile corresponding to only single kinase species (Fig. 2, $B$ ) and calculation data presented in Fig. 3 we determined the molecular weights and RMS radii for the oligomer and dimer MLCK species (Table 3). For the monomer we 
Table 2

Percent content of different MLCK species in solution at equilibrium

\begin{tabular}{lcc|c}
\hline \multicolumn{1}{c|}{ Kinase species } & otigomer & Dimer & Monomer \\
\hline $\begin{array}{l}\text { Contribotion to light scattering } \\
\left(I^{i}\right) \text { at equilibrium, \%* }\end{array}$ & 52.3 & 36.9 & 10.7 \\
$\begin{array}{l}\text { Relative contribution to light } \\
\text { scattering, } \delta^{i * *}\end{array}$ & 35.3 & 1.0 & 0.35 \\
$\begin{array}{l}\text { The amount in solution }\left(B^{i}\right) \text { at } \\
\text { equilibrium, wt. \% }\end{array}$ & 2.1 & 53.0 & 44.9 \\
\hline
\end{tabular}

*Data taken from text. For values of the index *i* values see Table 1; **Data taken from Table 1; *** Concentrations of different kinase species at equilibrium in wt. $\%$ were calculated from the following expression: $B^{i}-\left[\left(I^{i} / \delta^{i}\right):\left(I^{\circ} / \delta^{\omega}+I^{i} / \delta^{i}+I^{\mathrm{m}} / \delta^{\mathrm{m}}\right)\right] \cdot 100$.
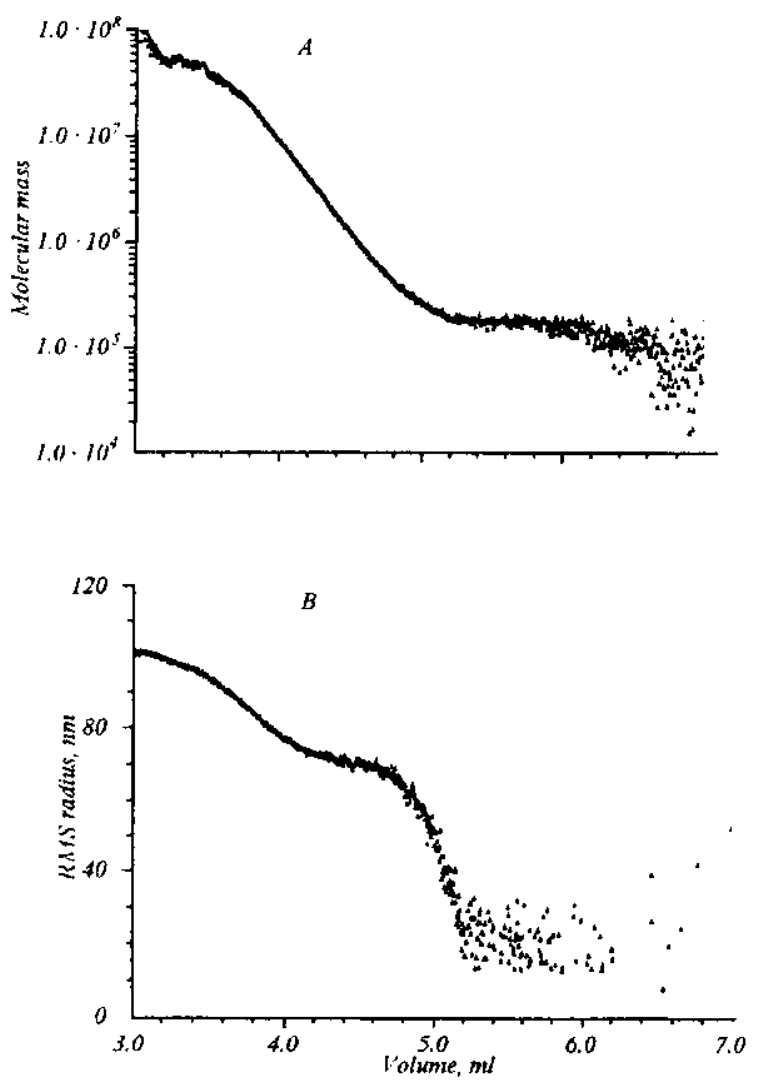

Fig. 3. MLCK molecular mass $(A)$ and RMS radius $(B)$ vs elution volume for gel-filtration column. Details see in the legend to Fig. 2

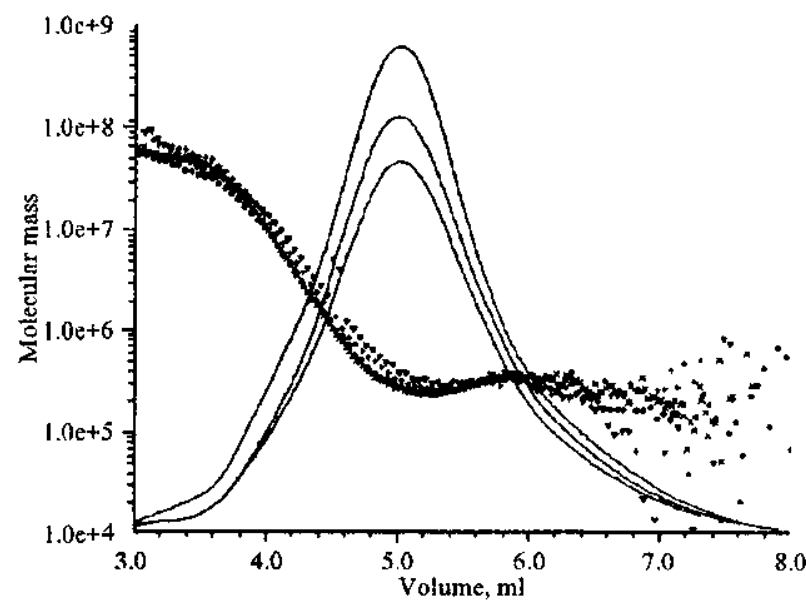

Fig. 4. Elution profiles and $M_{\mathrm{r}}$ vs elution volume for different MLCK to CaM molar ratio; 10:1 $(\mathrm{x}-\mathrm{x}), 5: 1(+--+), 1: 1.5(0--0)$ and without $\mathrm{CaM}(\nabla--\nabla)$. Total injected mass of kinase in all cases was $0.56 \mathrm{mg}$ and $0,1 \mathrm{mM} \mathrm{CaCl}$ was added to the elution buffer

were able to calculate only $M_{\mathrm{r}}$ because of its poor light scattering.

All the data given in Fig. 2 and 3 are obtained for the inactive kinase. However it is worth noting that kinase activation by binding to $\mathrm{CaM}$ at different apoenzyme to $\mathrm{CaM}$ ratios doesn't influence practically the elution profiles and the curves of the molecular weight and RMS radius vs. elution coordinate (Fig. 4). This indicates that wt \% ratio of the three kinase species remains nearly unchanged during the activation, which is in the agreement with the LCS data. The same was also confirmed in the experiments where $\mathrm{CaM}$ and kinase were syringed directly into the photometer flow cell immediately after their mixing in the presence of $\mathrm{Ca}^{2+}$ (data not shown).

A number of experiments were carried out with a $\mathrm{CM}$-affinity column. In the presence of $\mathrm{Ca}^{2+}$ ions MLCK binds to CaM covalently linked to the column matrix, and can be specifically eluted with a solution containing EGTA. Fig. 5 shows the elution profiles together with $M_{\mathrm{r}}$ and RMS radius dependencies calculated. As clear from Fig. 5, A, both elution profiles (UV-absorption, curve $I$, and light scattering, curve 2) nearly coincide indicating that the eluate practically contains a single kinase species. Fig. $5, B$ suggests that this species corresponds to the oligomer with RMS radius of about $80 \mathrm{~nm}$ similar to the one eluted from the gel-filtration column. In contrast, $M_{\mathrm{r}}$ 
FILENKO A. M

Table 3

Molecular weight and $R M S$ radius for different $M L C K$ species

\begin{tabular}{l|c|c|c}
\hline Kinase species & $\begin{array}{c}\text { Interval on the } \\
\text { elution curve, } \mathrm{ml}\end{array}$ & $\begin{array}{c}\text { Motecular mass, } \\
\text { Da }\end{array}$ & RMS radius, ont \\
\hline & $3.7-3.8$ & $1.0 \cdot 10^{7}$ & 80 \\
Oligomer & $5.2-5.7$ & $2.0 \cdot 10^{5}$ & 22 \\
Dimer & $6.4-7.0$ & $1.0 \cdot 10^{5}$ & - \\
Monomer & & & \\
\hline
\end{tabular}
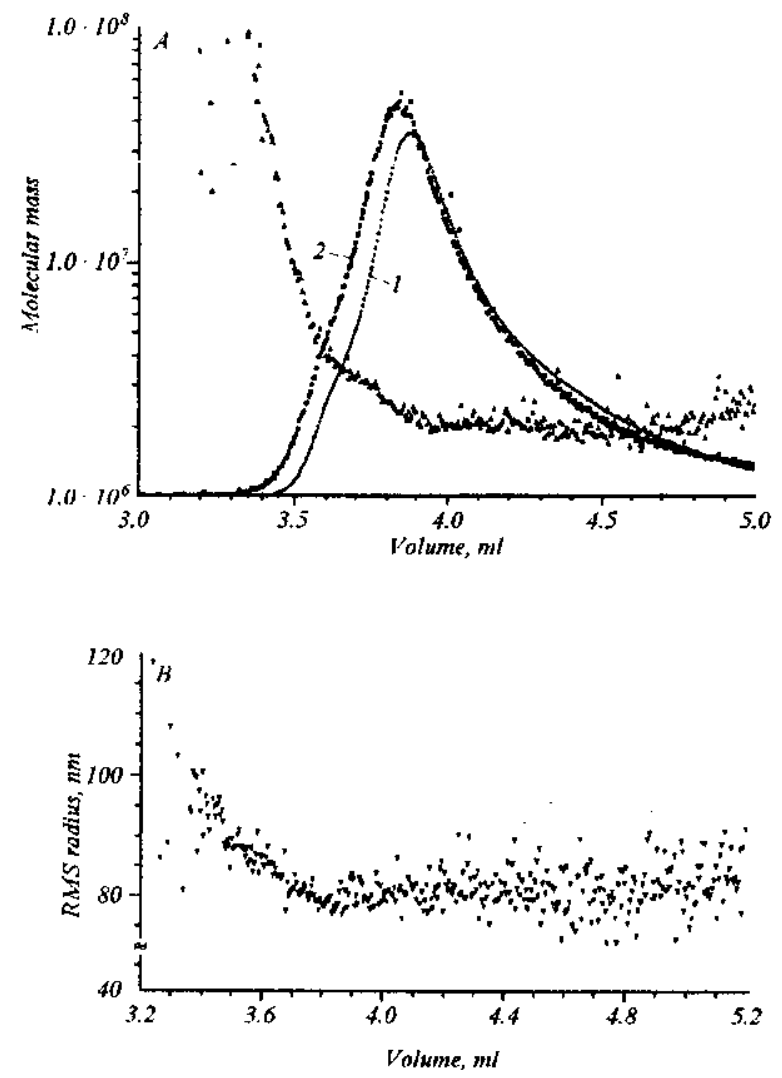

Fig. 5. MLCK $M_{\mathrm{f}}(A)$ and RMS radius $(B)$ vs elution coordinate for CaM-affinity column. For convenience UV absorption (curve $I$ ) and light scattering (curve 2) profiles are also included. $0.53 \mathrm{mg}$ (plus $0.1 \mathrm{mM} \mathrm{CaCl}$ ) was applied to the column; elution solution contained $2 \mathrm{mM}$ EGTA. Flow rate was $0.15 \mathrm{ml} / \mathrm{min}$

of this oligomer was about 10 times less than $M_{\mathrm{r}}$ of that from the gel-filtration column.

Experiments with pause in the elution process. As indicated in Materials and Methods the volume of tubing connecting the gel-filtration column with the flow cell of Wyatt photometer (delay volume) was about $0.26 \mathrm{ml}$. This means that at the elution rate of $0.25 \mathrm{ml} / \mathrm{min}$ the portion eluating from the column must reach the cell in about $1 \mathrm{~min}$. As could be seen from the above results the different MLCK species separated by the column remained nearly unchanged during this time. This means that mutual transition between these species at the approach to the equilibrium state is rather slow.

To have more detailed notion about the MLCK species stability we carried out a number of experiments with the elution interruption. Fig. $6, A$ and $B$, shows the results of two such experiments with the pauses in the elution from the gel-filtration column at 4 and $5 \mathrm{ml}$. As can be seen in Fig. 2, B, at the elution coordinate $5 \mathrm{ml}$ practically pure dimer is eluting from the column.

Therefore the elution pause in this point let us observe the process of dimer transition to the equilibrium state with the formation of two other kinase species - monomer and oligomer. As Fig. 6, $A$, shows this process continues for about $10 \mathrm{~min}$ indicating the stability of the dimer. The oligomer seems to be still more stable. Indeed, the elution pause at $4 \mathrm{ml}$, where eluate contains equal weight amounts of dimers and oligomer but light scattering is practically caused by oligomer species (Fig. 2, B), gives the process of very slow decrease of light scattering intensity which indicates on the very slow transition of the oligomer to the other kinase species (Fig. 6, B). Even after $20 \mathrm{~min}$ from the elution interaption the light scattering intensity is reduced only by about $11 \%$ which indicates the transition of only small amounts of oligomer into other kinase species during this time.

Discussion. The light scattering data obtained in this investigation show that in solution MLCK exists as the equilibrium mixture of the oligomeric, dimeric and monomeric species. The preliminary experiments (not given here) revealed that the polymer species percentage decreased at ionic strength increasing. At the ionic strength of $60 \mathrm{mM}$ (original buffer AA) the kinase solution opalescences, which indicates a high amount of the oligomer species. Upon the addition of $300 \mathrm{mM} \mathrm{NaCl}$ to the buffer almost only dimer and monomer were present in the solution at the excess of the latter. The ionic strength of $160 \mathrm{mM}$ chosen in our experiments turned out to be optimal for the distinct separation of the individual MLCK species, their percentage estimation in both equilibrium state and the eluate and for their properties investigation.

According to our data (Table 3) the dimer molecular mass is about $2.0 \cdot 10^{5} \mathrm{Da}$ which is in good agreement with the monomer molecular mass $M_{\mathrm{r}}=$ 


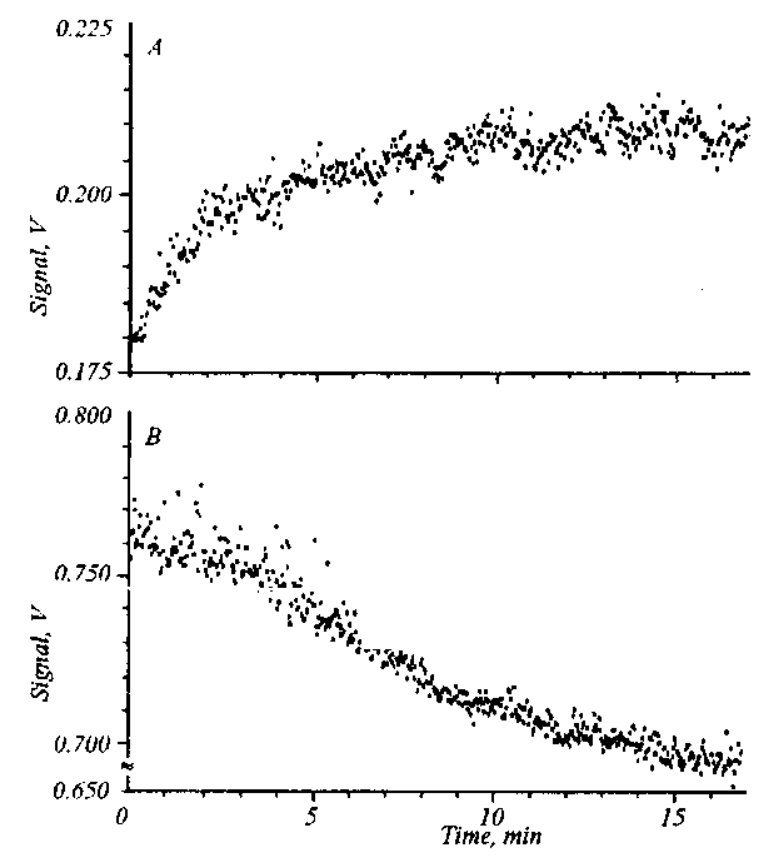

Fig. 6. Time-dependent changes of MLCK light scattering after interruption of the elution from gel-filtration column at $5 \mathrm{ml}(A)$ where practically pure dimer is present and at $4 \mathrm{ml}(B)$ (oligomer + dimer). For more details see text

$=1.06 \cdot 10^{5} \mathrm{Da}$ calculated by Olson et al. [23] from the amino acid sequence. Ausio et al. [19] have shown by analytical ultracentrifugation that MLCK molecule has the rod-like shape of length $L=50 \mathrm{~nm}$, diameter $d=2.15 \mathrm{~nm}$, the axial ratio 19 and RMS radius $R_{\mathrm{g}}=$ $=14.4 \mathrm{~nm}$. By definition [12] RMS radius is

$$
R_{g}=\sqrt{\left[(1 / M) \int_{m}^{2} d m\right]}
$$

where the integration is over mass elements of the particle with respect to the center of its gravity.

From (1) for rod-like particle we have

$$
R_{\mathrm{g}}=L / 2 \sqrt{3},
$$

where $L$ is the rod length. The axial ratio for MLCK dimer is 32 [19]. This indicates that at the axial ratio 19 for the kinase monomer its dimer length is $\mathbf{1 . 2}$ times less than double length of the monomer. Hence we may calculate RMS radius for the dimer $R_{\mathrm{g}}=$ $=\left(2 L_{\mathfrak{m}} / 1.2\right) / 2=24 \mathrm{~nm}$. In our experiments we ob- tained the close value of $R_{\mathrm{g}}=22 \mathrm{~nm}$ (Table 3). The above-mentioned authors have not discovered the oligomer species since their investigations were made at rather high ionic strength $(0.2 \mathrm{M} \mathrm{NaCl})$ and high sucrose concentration. These factors strongly reduce the ionic and hydrophobic interactions, which are mainly responsible for the supramolecular structure formation.

Taking into consideration relatively small increase of the oligomer RMS radius with respect to that of the dimer (about 4-fold) at about 102-fold difference in their molecular masses (Fig. 3) we may suggest several models for the oligomer structure organization.

Ring structure, where MLCK molecules are associated in head-to-tail fashion (Fig. 7, $A$ ). It is not difficult to show using equation (1) that for the ring, thickness of which may be neglected, RMS radius is determined by the expression

$$
R_{\mathrm{g}}=\sqrt{\left(R^{2}+h^{2} / 12\right)},
$$

where $R$ and $h$ are the ring radius and height respectively. Hence even at $h=R / 2$ we have $R_{8}=$ $=1.01 R$, so in our reasoning we may suppose with sufficient accuracy that RMS radius of the MLCK ring structure $\left(R_{\mathrm{g}}=80 \mathrm{~nm}\right)$ is equal to its geometrical radius. Therefore at the association of the kinase molecules without overlapping the ring must contain $\left(2 \pi R_{\mathrm{g}} / L^{\pi i}\right)=2 \pi \cdot 80 / 50 \approx 10$ molecules. At the monomer molecular mass of $1.06 \cdot 10^{5} \mathrm{kDa}$ the molecular mass of such ring structure must be $M_{r}^{\circ}=10^{\circ} \mathrm{Da}$. We obtained for MLCK oligomer $\mathrm{M}_{r}^{0} \approx 10^{\gamma} \mathrm{Da}$ (Table 3). This suggests that the ring structure must be turned up into a helix with a number of turns $n=10$. At such number of turns and the MLCK monomer diameter equal $2.15 \mathrm{~nm}$ the helix height at the compact packing is supposed to be $h=2.15 \cdot 10=22 \mathrm{~nm}$. It must be noted that such helix structure is much closer to a spherical form than the rod-like monomer and dimer. It might be the reason why the oligomer size obtained by the LCS method (158 $\mathrm{nm}$, see up) corresponds rather well to the size obtained by the Wyatt DAWN photometer measurements $\left(D=2 R_{\mathrm{g}}{ }^{\circ}=160 \mathrm{~nm}\right)$.

Rod-like structure may also account for the data obtained (Fig. 7, B). Indeed at $R_{8}^{\circ}=80 \mathrm{~nm}$ we may find from (2) the rod length $L=2 \sqrt{3} R_{\mathrm{g}}{ }^{\circ} \approx 280 \mathrm{~nm}$, which at the monomer length $50 \mathrm{~nm}$ [19] correlates well with 6 kinase molecules (hexamer) arranged in line forming one «building unit». Molecular mass of the oligomer at the exit from gel-filtration column is $M_{\mathrm{r}}^{0}=10^{7} \mathrm{Da}$, which corresponds to about 100 monomer molecules. Accordingly at the rod-like oligomer structure the last must contain about 17 such building units arranged in parallel. In the oligomer with $M_{\mathrm{r}}^{\circ}=$ 


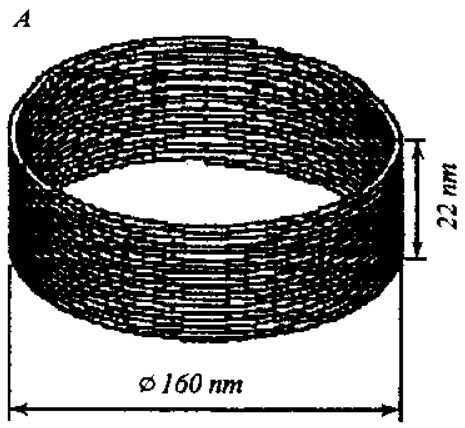

$B$
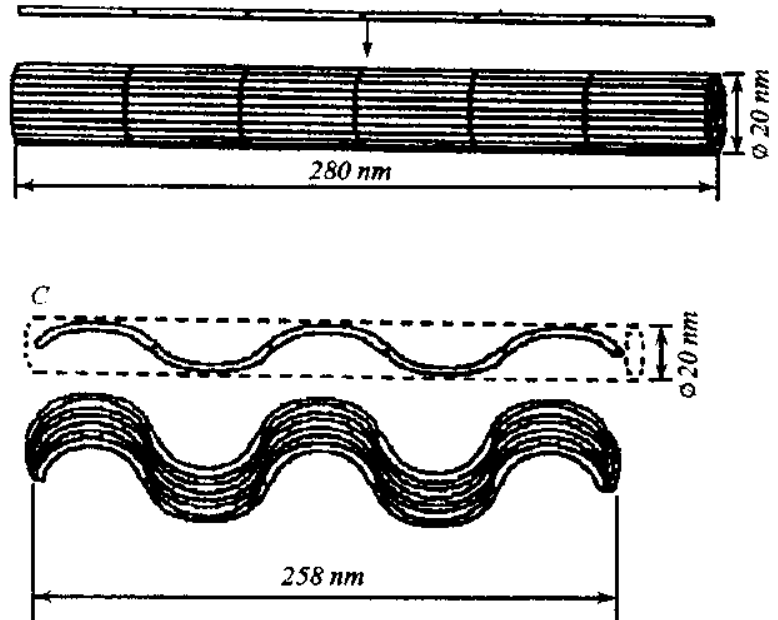

Fig. 7. Possible models of MLCK oligomer organization: ring structure $(A)$, rod-like structure $(B)$, and spiral structure $(C)$. Details see in the text

$=2.4 \cdot 10^{6} \mathrm{Da}$ at the exit from CaM affinity column (Fig. 5, $A$ ) there should be only four such building units with 6 molecules.

Spiral structure (Fig. 7, C). The 6-molecule unit may be also interpreted as an extended spiral structure. From (1) we can get for a spiral

$$
\left.R_{\mathrm{g}}=\sqrt{\left[\vec{R}^{2}+(c N)^{2}\right.} / 12\right]=\sqrt{\left(\hat{R}^{2}+H^{2} / 12\right)},
$$

where $R, c, N$ and $H$ are radius, pitch, number of turns, and height of a spiral, respectively. Such 6-molecule spiral structure with $R=10 \mathrm{~nm}$ and $H=$ $=258 \mathrm{~nm}$ (Fig. 7, C) fits well to smooth myosin filament with which the kinase is tightly associated.
We used this spiral structure model to interpret a possible location of the kinase molecules on myosin filaments in vivo (see details in [24]). In solution such extended spiral structures should get together into the associates analogous to the above described rod-like model. In case of the rod-like or spiral structures it is reasonable to suggest that 6 molecule unit is a real oligomer and that the structures registered by light scattering are the aggregates formed by these unites.

Attention should be paid to the strong increase in the supramolecular kinase species in eluate (Table 1) in comparison with their content in the equilibrium state (Table 2). This may be explained by the fact that translational motility of eluting protein molecules in rather small cells of the column bed is restricted. Consequently the main entropy factor preventing the weak interactions, which are basically responsible for the formation of supramolecular structures $[1]$, is reduced essentially. Analogous role in restriction of translational motility of protein molecules must be fulfilled by cytoplasmic structures of living cell. Therefore this experimental fact may point indirectly to a significant role of the oligomeric and dimeric species in vivo.

It is of interest to compare the results obtained at the elution pauses (Fig. 6) with the calculated data. At the elution interuption in the point $5 \mathrm{ml}$ practically pure MLCK dimer is present in the eluate at the column outlet (Fig. 2, A). Light scattering registration of the eluate portion, which reaches DAWN photometer flow cell, begins in about $1 \mathrm{~min}$ from the moment of its exit from the column. Exponential extrapolation of the curve presented in Fig. 6, $A$, to the moment of the eluate exit results in the original light scattering level (corresponding to the pure dimer) $I_{0}=0.160$. This curve goes up to the constant light scattering level $I_{c}=0.215$. So the gain of light scattering intensity must be $\Delta I=[(0.215-$ 0.160 ) $/ 0.160] \cdot 100=34 \%$. This level corresponds to the attainment of the equilibrium between three kinase species. It is not difficult to see that $i$-th kinase species gives contribution into light scattering $\left(0.160 \cdot B^{i} \cdot \delta^{i}\right) / 100$ (see Table 2 ). Hence individual contributions for the oligomer, dimer and monomer must be $0.117,0.085$ and 0.025 , respectively, which gives in sum the level of scattering at equilibrium 0.227 . This corresponds to the total gain against the original level $[(0.227-0.160) / 0.160] \cdot 100=42 \%$ which rather well agrees with the experimental value of $34 \%$. The discrepancy in these values may be due to some inaccuracy of the data obtained by the LCS method, which were used for calculation of values $B^{i}$, not high accuracy of the determination of the mono- 
mer contribution $\delta^{\mathrm{m}}$ into light scattering and possibly to some instability of DAWN photometer in the conditions of flow interaption.

Fig. 6 shows that the MLCK oligomers and dimers are long living stable structures. We suppose that the oligomer assemblage goes through association of individual MLCK molecules in head-to-tail fashion. If the orientation of the MLCK molecules in the dimer was the same being the first step on the pathway of oligomer assembling it would be hard to understand why other intermediate forms such as trimer, tetramer etc. could not be discovered.

The most competent explanation of this observation is that the dimers of head-to-tail fashion are unstable, transitional, short-living species on the pathway of oligomer assembling while the long-living dimers discovered in solution are formed by the MLCK molecules associated in tail-to-tail or head-tohead fashion. Thus we can suppose that the most probable scheme of the mutual species transition is: Oligomer $\leftrightarrow$ Monomer $\leftrightarrow$ Dimer and therefore the formation of the dimer and oligomer species must go through the step of monomer.

Conclusions and remarks. The main results of our investigations are the following:

1. In solution under conditions close to physiological the smooth muscle myosin light chain kinase exists as a mixture of monomers, dimers and oligomers. At equilibrium the contribution of these forms in weight percents is 45,53 and 2, respectively. Such proportion of different kinase species is characteristic for both apoenzyme and activated kinase. An important point is that supramolecular MLCK species in the eluate were strongly increased in comparison with their content in equilibrium state. The contributions of the kinase oligomer, dimer and monomer in the eluate at the exit from gel-filtration column were $5.3,81.5$ and 13.2 wt. \% accordingly. At the exit from CaM-affinity column we obtained practically pure oligomer. Such oligomer in comparison with the gel- filtration one had 3 times less $M_{\mathrm{r}}$ and its time of transition to the equilibrium state was significantly less.

2. All three kinase species are characterized by prolonged lifetime. The transfer from the state of pure dimer into equilibrium state lasts about $10 \mathrm{~min}$. The same is true for the oligomer at the exit from CaM-affinity column. But the oligomer with much greater $M_{\mathrm{r}}$ (or more exactly oligomer aggregates) at the exit from gel-filtration column is much more stable and transfer from it to the equilibrium lasts for more extended time.

3. Oligomer is characterized by RMS radius $R_{\mathrm{g}}$ $\approx 80 \mathrm{~nm}$. The oligomer structure may be presented as a helical ring containing about 10 kinase molecules per turn with a number of turns about 10 (data for gel-filtration column). Another possible and more realistic explanations of the data obtained involves the rod-like or spiral models according to which 6 kinase molecules arranged in line or prolonged spiral form a structural unit which must be a real oligomer (hexamer). About 17 such structural units associated in parallel may form aggregates with molecular mass of about $10^{7} \mathrm{kDa}$. The kinase elongated spiral hexamer fits well to the structure of smooth myosin filament with which the kinase is in close contact in vivo [25, 26 ].

The possibilities of the light scattering methods used and peculiarities of their usage.

a) LCS allows to discover particles with different molecular masses, find out their percent contribution into intensity of light scattering and determine the dimensions of spherical particles. For spherical particle the average diameter $D_{\mathrm{av}}$ obtained by this method is equal to the diameter of hydrated molecule. In our case of rod-like particles $D_{a v}$ presents some average value which is far from real dimensions of these molecular forms. The most, which we could get by only this approach, was the quantity of particle species in solution, contribution of different species into light scattering and the fact that dimer dimension is twice that of the monomer. We were able to find out wt. \% equilibrium distribution for different kinase species only by comparison the LCS data with the results of multi-angle light scattering analysis of the kinase eluate.

b) Multi-angle light scattering photometry in conjunction with FPLC permited to determine molecular masses and RMS radii for the kinase dimer and oligomer (for monomer only RMS radius due to low light scattering), wt. \% distributions of different species in eluate, specific (per mass unit) light scattering of different species (which together with the LCS data allowed to estimate weight ratio for different kinase species in equilibrium solution).

c) LCS and multi-angle light scattering used together give more complete information about the pattern of different particle distributions in solution and characterization of these particles.

d) The procedure of decomposition of mass sensitive and light scattering elution profiles into individual monopeaks used in this study for the first time enables more careful analysis of the data obtained.

e) Interruption of elution at specified points used in this study allows to evaluate the time of transfer of different protein species to the equilibrium state. 
M. Філенко

Дослідження олігомерних форм білхів методами світлорозсіювання: надмолекулярні структури кінази легких ланцюгів міозину гладеньких м'язів

Резкоме

Сучасні методи багатокутового світлорозсіювання в поєднанні зі швидкісною хроматографією білків та лазерною кореляційною спектроскопісю дають досить детальну інформацію щодо розподілу білкових частинок у розчині, іхнього розміру та молекулярної маси. Дані, отримані при дослідженні кінази легких ланцюгів міозину гладеньких м'язів, свідчать про те, ио цей білок існує в розчині як рівновахна суміи олігомерних, димерних та мономерних часток у кількісному співвідноменні 2, 53 та 45 вагових \% відповідно. На виході 3 гель-фільтраційної колонки рівновага значно зсунута в бік олігомерних форм кінази $і$ иас переходу до рівновахного стану становить приблизно 10 хв. Динер кінази мас стрихнсынду структуру з середньоквадратичним радіусом (СКР) біля 22 нм. Для олігомеру СКР складає біля $80 \mathrm{\mu м}$. Його структуру можна представити у вигляді спірального кільця із 10 витків 310 молекулами кінази на виток. Структуру олігомера добре описують також стрижневидна або спіралевидна моделі 3 иістьма молекулами, розміщеними вздовж лінії або витяснутої спіралі. Біля 17 таких шестимолекулярних елементів утворюють паралельно асоційовані агрегати. Попередні дослідження показали, мо низка інших білків також існуе в розчині як рівновахна суміш мономерів $і$ надмолекулярних структур $з$ тривалим часом життя.

\section{A. М. Филенко}

Исследование олигомерных форм белков методами светорассеяния: надмолекулярные структуры киназы легких цепей миозина гладких мышц

\section{Резюме}

Современные методы многоуглового свсеторассеяния совме стно со скоростной хроматографией белков и лазерной корреляционной спектрскопией дают достаточно полную информацию о распределении белковых частиц в растворе, их размере и молекулярной массе. Даннье, полученнье при исследовании киназы легких цепей миозина гладких мыши, свидетельствукот, что этот белок существует в растворе как равновесная смесь олигомерньх, димерных и мономерных частиц в количественном соотноиении 2,53 и 45 весовых \% соответственно. На выходе из гель-фильтрационной колонки равновесие сильно сдвинуто в сторону олигомерных форм киназы и время перехода в равновесное состояние составляет приблизительно 10 мин. Димер киназы имеет стержневидную структуру со среднеквадратичньм радиусом (СКР) около 22 нм. Дия олигомера СКР составляет около 80 нм. Его структуру можно представить в виде спирального кольца из 10 витков с 10 молекулами киназы на виток. Структуру олигомера хорошо описывают также стержневидная ити спиралевидная модели с иестью молекулами, размещенными вдоль линии или вытянутой спирали. Около 17 таких шестимолекулярных элементов образуют параллельно ассочиированные аррегать. Предварительные исследования показали, что ряд других белков такхе существует в растворе как равновесная смесь мономеров и надмолекулярных структур с продолжительньм временем жизни.

\section{REFERENCES}

1. Schulz G. E., Schirmer R. H. Principles of protein structure // New-York: Springer, 1979.-316 p.

2. Mayr G. W., Heilmeyer $L . M$. J. Skeletal muscle myosin light chain kinase. A refined structural model // FEBS Lett.1983.-157, N 2.-P. 225-231.

3. Mayr G. W. Interaction of calmodulin with muscle phosphofructokinase // Eur. J. Biochem.-1984.-143, N 3.P. $513-520$.

4. Mayr G. W. Interaction of calmodulin with muscle phosphofructokinase. Interplay with metabolic effectors // Eur. J. Biochem. - 1984.-143, N 3.-P. 521-529.

5. Kosk-Kosicka D., Bzdega T., Wawrzynow A., Scaillet S., Nemcek $K$. Johnson J. D. Erythrocyte $\mathrm{Ca}^{2+}$-ATPase: activation by enzyme oligomerization versus by calmodulin // Calcium Binding Proteins in Normal and Transformed Cells / Eds R. Pochet, D. Eric, M. Lawson, C. W. Heizmann.-New York: Plenum Publ. Cor., 1990.-P. 169-174.

6. Flapper $W$., van der Oetelaar P. L, Breed C. P., Steenbergen $J$., Hoenders $H$. J. Detection of serum proteins by high-pressure gelpermeation chromatography with low-angle laser ligh scattering, compared with analytical ultracentrifugation // Clin. Chem.-1986.-32, N 2.-P. 363-367.

7. Hayashi Y., Matsui H., Takagi T. Membrane protein molecular weight determination by low-angle laser light-scattering photometry coupled with highperformance gel chromatography // Meth. Enzymol.-1989.-172, N 1.-P. 514-528.

8. Kijima Y., Takagi T., Shigekawa M., Tada M. Protein-protein interaction of detergent-solubilized $\mathrm{Ca}^{2+}$-ATPase during ATP hydrolysis analyzed by low-angle laser light scattering photometry coupled with high-performance gel-chromatography // Biochim. et biophys. acta.-1990.-1041, N 1.-P. 1-8.

9. Rarity J. G., Owens P. C., Atkinson T., Seabrook R. N., Carr $R$. J. Light scattering studies of protein association // Biochem. Soc. Trans. $-1991 .-19$, N 2.-P. 489-490.

10. Wen J., Arakawa T., Philo L. S. Size exclusion chromatography with on-line light-scattering, absorbance, and refractive index detectors for studying proteins and their interactions // Anal. Biochem. $-1996 .-240$, N 2.-P. $155-166$.

11. Kunitani $M$., Wolfe S., Rana S., Apicella C., Levi $V$. Dollinger $G$. Classical light scattering quantitation of protein aggregates: off-line spectroscopy versus HPLC detection // J. Pharm. Biomed. Anal. $-1997 .-16, N$ 4.-P. 573-586.

12. Wyat $P . J$. Calcium transients and resting levels in isolated smooth muscle celis monitored with quin $2 / /$ Anal. chim. acta.-1993.-272, N 3.-P. 1-40.

13. Sobieszek A., Barylko $B$. Enzymes regulating myosin phosphorylation in vertebrate smooth muscle // Smooth Muscle Contraction /Ed. N. L. Stephens.-New York: Marcel Dekker, 1984-P. 283-316.

14. Sobieszek $A$. Regularion of smooth muscle myosin light chain kinase // J. Mol. Biol,-1991.-220, N 5.-P. 947-957.

15. Sobieszek A., Strobl A., Ortner B., Babiychuk E. Ca ${ }^{2+}$-calmodulin-dependent modification of smooth-muscle myosin light chain kinase leading to its co-operative activation by calmodulin // Biochem. J.-1993.-295, N 5.-P. 405-411.

16. Adelstein R. S., Klee C. B. Purification and characterization of smooth muscle myosin light chain kinase // J. Biol. Chem.-1981.-256, N 14.-P. 7501-7509.

17. Braginskaya T. G., Dobichin P. D., Ivanova M. A. Analysis of polydispersity by photon correlation spectroscopy // Phys. Scripta.-1983.-26, N 5.-P. 309-315.

18. Nicoli D. F. McKenzie D. C., Wu J.-S. Application of dynamic light scattering to particle size analysis of macromolecules // Int. Lab. -1992 . -24, N 8.-P. 32-37. 
19. Ausio J., Malencik D. A., Anderson S. R. Analytical sedimentation studies of turkey gizzard myosin light chain kinase // Biophys. J.-1992. -61, N 8.-P. 1656-1663.

20. Lowey S., Goldstein L., Cohen C., Luck S. M. Proteolytic degradation of myosin and the meromyosins by a water-insoluble polyanionic derivative of trypsin: properties of a helical subunit isolated from heavy meromyosin // J. Mol. Biol.1967.-23, N 3.-P. 287-307.

21. Carlson F. D., Fraser A. B. Intensity fluctuation autocorrelation studies of the dynamics of muscular contraction // Photon Correlation and Light Beating spectroscopy / Eds H. Z. Cummins, E. R. Pike.-New York: Plenum press, 1974.P. 519-532.

22. Privalov $P . L$ Stability of proteins. Proteins which do not present a single cooperative system // Adv. Protein Chem.1982. - 35, N 3. $\rightarrow$ P. $1-104$.

23. Olson N. J., Pearson R. D., Needleman D. S., Hurwitz M. Y.,
Kemp B. E., Means A. R. Regulatory and structural motifs of chicken gizzard myosin light chain kinase // Proc. Nat. Acad. Sci. USA. - 1990.-87, N 6.-P. 2284-2288.

24. Filenko A. M., Danilona V. M., Sobieszek A. Smooth muscle myosin light chain kinase, supramolecular organization, modulation of activity, and related conformational changes // Biophys. J. $-1997 .-73$, N 4.-P. 1593-1606.

25. Sobieszek $A$. Vertebrate smooth muscle myosin: enzymatic and structural properties // The Biochemistry of Smooth Muscle / Ed. N. L. Stephens.-Baltimore: Univ. Park press, 1977.P. 413-443.

26. Sobieszek $A$. Cross-bridges on self-assembled smooth muscle myosin filaments // J. Mol. Biol._1972. -70, N 4.-P. 741744.

удК 591.175 .4

Received 15.06.99 